The 'Tragedy' of Charlie Gard: a case study for regulation of innovation?

Jonathan Montgomery*

Faculty of Laws, University College London

Faculty of Laws, University College London, Bentham House, Endsleigh Gardens, London WC1H 0EG.

Jonathan.Montgomery@ucl.ac.uk 


\title{
The 'Tragedy' of Charlie Gard: a case study for regulation of innovation?
}

Jonathan Montgomery*

\begin{abstract}
Reflections on the Charlie Gard litigation suggest that procedural regulation is important to prevent tragic cases becoming 'tragedies'; where well-intentioned but overconfident doctors and parents conflict in ways that are deeply destructive.
\end{abstract}

ARTICLE HISTORY Received 13 November 2018; Accepted 3 January 2019

KEYWORDS novel therapies; tragic dilemmas; judicial oversight; right to try; parental choices

\section{Introduction}

Charlie Gard's case offers an opportunity to consider the regulation of innovation in tragic circumstances. This article suggests that a useful perspective for assessing the regulatory framework for innovation 'in extremis' - cases of last resort at the edge of life - can be found in the ancient literary form of 'tragedy', in which circumstances expose character 'flaws' that lead the protagonists to destruction. ${ }^{1}$

\footnotetext{
* Faculty of Laws, University College London, Bentham House, Endsleigh Gardens, London WC1H 0EG, Jonathan.Montgomery@ucl.ac.uk.

${ }^{1}$ For the idea of 'tragedy', see Henry Ansgar Kelly, Ideas and Forms of Tragedy from Aristotle to the Middle Ages (Cambridge University Press 1993); Julian Young, The Philosophy of Tragedy (Cambridge University Press 2013).
} 
Schopenhauer suggests that the essence of tragedy is that destructive forces lie in the compulsions of human commitments. It is not a matter of wickedness, but the consequences are deeply destructive despite good intentions. As Iris Murdoch quotes, ${ }^{2}$

... characters of ordinary morality... are so situated with regard to each other that their position compels them knowingly and with their eyes open to do each other the greatest injury without any one of them being entirely in the wrong.... misfortune, not ... occasioned by rare or monstrous characters, but as arising easily and of itself out of the actions and characters of men, indeed as almost essential to them. ${ }^{3}$

Murdoch's summarises the essence of the Shakespearean tragedy, King Lear: 'Those who refuse to compromise reasonably with what they see as evil may well destroy themselves and their innocent friends and achieve nothing - except perhaps to leave an example behind.' 4

Charlie Gard was born on 4 August $2016 .{ }^{5}$ Within weeks it became apparent that his development was slow and he was not gaining weight. He became lethargic, his breathing became shallow and he was transferred to Great Ormond Street Hospital (GOSH) in London on 11 October 2016. His parents were provided with accommodation at the hospital so that they could stay with him. He remained at that

${ }^{2}$ Iris Murdoch, Metaphysics as a Guide to Morals (Chatto \& Windus 1992) 101.

${ }^{3}$ Arthur Schopenhauer, World as Will and Idea, Book III, 'The Platonic Idea: The Object of Art.'

${ }^{4}$ Murdoch (n 2) 119.

${ }^{5}$ Unless otherwise indicated, this summary of facts is taken from the judgment of the High Court, the only body that heard expert evidence, tested it in cross-examination, and considered representations of counsel for the parents and hospital; Great Ormond Street Hospital v Yates and Gard [2017] EWHC 972 (Fam) [44]-[93] ('Gard'). For the assessment of the factual situation in July 2017, see [2017] EWHC 1909 (Fam) ('Gard II'). 
hospital until the High Court ruled on 27 July 2017 that he could be moved to a hospice. Charlie died the following day. ${ }^{6}$

Charlie was born with a rare mitochondrial disease known as infantile onset encephalomyopathic mitochondrial DNA depletion syndrome, a progressive disease that severely affected his brain, muscle and ability to breathe, with the prognosis of further deterioration. He suffered from congenital deafness and a severe epilepsy disorder. His heart, liver and kidneys were also affected but (according to a second opinion of April 2017) not severely. In November 2016, the clinical team at GOSH was concerned that this quality of life was too poor to justify subjecting him to long-term ventilation and took advice from the hospital Ethics Committee, which concluded that it would not be appropriate to offer a tracheotomy. By the time of the first court hearing in April 2017 it was found that Charlie's 'muscle condition and/or neurological condition [were] so poor that the only way to tell that he [was] having or ha[d] had an epileptic seizure [was] to monitor brain activity' ${ }^{7}$

Charlie's mother identified a professor in the USA who was researching nucleoside therapy, although it had not been used, even in mice, for the condition by which Charlie was affected. Extensive consideration was given to trying this therapy; the GOSH doctors discussed it with the USA professor and drafted an application intended to go to the hospital Ethics Committee meeting of 13 January 2017 for approval to attempt it. However, around 9 or 10 January 2017, Charlie suffered a series of seizures, his condition deteriorated, and an internal case conference concluded that it would be futile to attempt the nucleoside therapy. Consequently, they withdrew the

6 'Charlie Gard parents announce death of 'beautiful boy' 28 July 2017 , https://www.bbc.co.uk/news/uk-england-london-40752120 (accessed 26 July 2018).

${ }^{7}$ Yates and Gard v Great Ormond Street and Charles Gard [2017] EWCA Civ 410, [17] ('Gard $\left.C A^{\prime}\right)$. 
Ethics Committee application. The parents still wanted to try the experimental therapy and the hospital placed the situation before the court.

The High Court ruled in April 2017 that it was not in Charlie's best interest to have his life prolonged and undergo the treatment. ${ }^{8}$ It reconsidered the situation in July 2017 and held that there was no new evidence to displace this conclusion. ${ }^{9}$ On appeal, the parents failed to show that the judge's assessment of the facts was flawed. ${ }^{10}$ Their challenges to the judge's finding that the legal test to be applied was what was in Charlie's best interests, failed before the Court of Appeal, ${ }^{11}$ the UK Supreme Court, ${ }^{12}$ and the European Court of Human Rights. ${ }^{13}$ The issues were, thus, extensively aired and the evidence tested in contested judicial proceedings. The findings of fact that were made in court are adopted in this article, being the most objective and reliable account of the medical circumstances available for outside consideration.

\section{Tragic choices and the avoidance of Tragedy}

The situation in which Charlie Gard was placed by his illness was 'tragic' because the stakes were high, fundamental values were at stake, and none of the available choices was easy or obviously the right one. ${ }^{14}$ As Rosalind Hursthouse has explained, a tragic dilemma is one where the virtuous actor cannot emerge unscathed even if they act in

${ }^{8} \operatorname{Gard}(\mathrm{n} 5)$.

${ }^{9}$ Gard II (n 5).

${ }^{10} \operatorname{Gard} C A(\mathrm{n} 7)$.

${ }^{11}$ Ibid.

${ }^{12}$ The reasons for the Supreme Court refusing permission are set out at https://www.supremecourt.uk/news/latest-judgment-in-the-matter-of-charlie-gard.html and https://www.supremecourt.uk/cases/docs/charlie-gard-190617.pdf (accessed 15 October 2018).

${ }^{13}$ Gard v UK Application no. 39793/17, 3 July 2017; [2017] ECHR 605.

${ }^{14}$ Guido Calabresi \& Philip Bobbitt, Tragic Choices (WW Norton 1978). 
accordance with good character. ${ }^{15}$ The 'tragedy' of the situation is something different. It lies in the possibility that good intentions might become destructive. The character traits that are central to the 'tragedy' of Charlie's case are not those of the many outsiders who interfered for their own purposes; President Trump, the aggressive spokesman for the family, the US pro-life pastor, and even the Pope. ${ }^{16}$ The tragedy lies in the possibilities that noble desires - doctors' belief in the power of medicine to cure and parents' love for their son - could become destructive in the circumstances of the case. Beneficence could collapse under the weight of medical hubris. Love could become obsessive and obscure rather than illuminate evidence to support decisions about the care to which Charlie was entitled.

One of the governance challenges for the law in this area is to provide constraints that serve to protect children against possible tragic consequences of these character 'flaws' without denying the proper impulses that lie behind them. This issue can arise in two rather different legal fields; the law relating to decision making without court oversight, and the rules that could govern judicial consideration. This article is primarily concerned with the former scenario, not least because it is relatively neglected in comparison to the latter. ${ }^{17}$ My aim is to examine how legal structures might help

${ }^{15}$ Rosalind Hursthouse, On Virtue Ethics (Oxford University Press 1999), 'Tragic Dilemmas', 71 77.

${ }^{16}$ For an introduction, and links to coverage, of these aspects, see Neera Bhatia, 'Three ways the Charlie Gard case could affect future end-of-life cases globally' The Conversation https://theconversation.com/three-ways-the-charlie-gard-case-could-affect-future-end-of-lifecases-globally-81168 (accessed 23 July 2018).

${ }^{17}$ Although for a broader overview see Dominic Willkinson \& Julian Savalescu 'Alfie Evans and Charlie Gard - should the law change?' (2018) BMJ 361:k1891, doi: 10.1136/bmj.k1891. 
ensure that sound decisions are not overtaken by these character 'flaws'. In short, how they might prevent a hard and agonizing case becoming a 'tragedy' ${ }^{18}$

There are reasons to be concerned that medical hubris, both at GOSH and in New York, may have overtaken the proper consideration of Charlie's interests. There is a significant contrast, however, between the team at GOSH submitting its decisions to judicial scrutiny and Dr Hirano expressing his views without examining the patient or reading the court findings. This does not tell us which view was soundest, only that one was more careful about assessing the evidence and more subject to checks and balances than the other. The 'regulatory opportunity' to 'control and channel conduct' ${ }^{19}$ it is suggested, lies in procedural accountability as much (if not more) as in substantive principles.

Similarly, there are reasons to be concerned that the parents' wish for Charlie to get better may at times have overwhelmed their rational consideration of the evidence. ${ }^{20}$ This does not show that their hope was inappropriate. However, it may suggest that it would have been wrong to accept it at face value without eliciting the basis of their decisions and putting them under scrutiny; examining the consistency of the accounts that they gave for their decisions. A comparison with the approaches taken to assessing the competence of patients to determine their own care provides some insight, but also

${ }^{18}$ Barry Hoffmaster \& Cliff Hooker, 'Tragic Choices and Moral Compromise: The Ethics of Allocating Kidneys for Transplantation' (2013) Millbank Quarterly 9(3) 528-557.

${ }^{19}$ Roger Brownsword, Rights, Regulation, and the Technological Revolution (Oxford University Press 2008) 7.

${ }^{20}$ For discussion of this aspect of parental decision making for bone marrow transplantation, see Camilla Scanlan, Cameron Stewart and Ian Kerridge, 'Decision making in the shadow of death' (2016) American Journal of Bioethics 16(5) 23. Thanks to Tina Cockburn for this source. 
raises questions about whether proxy decision-making raises differences. Perhaps a better analogy would be the way in which expert medical evidence is tested. ${ }^{21}$

It is important to disentangle different types of arguments. Some concern the rationality and coherence of choices being made to try untested technologies. These can, in principle at least, be subjected to formal criteria that are relatively objective (that is, assessable by third parties), and substantially independent of the tragic nature of the circumstances. This type of argument is different from those concerning the acceptability of risk to the parties. Such arguments are inherently subjective as they depend on the 'appetite' for risk of those involved. This may not be aligned between the parties to the decision, who may agree on how the risks of harm and chance of benefit are to be defined and quantified but reach different conclusions on whether they constitute risks worth taking. The acceptability of risk is also heavily contextdependent; a small chance of success when the only available alternative is death will feel different to many than the same statistical chance when other options might be available.

These types of arguments differ again from clashes over the ways in which life should be valued. Here, there is considerable scope for disagreement about whether assessments should be made from a subjective or objective perspective. In relation to decisions about one's own life, anything other than a subjective valuation seems paternalist. However, this does not necessarily extend to proxy decision-making, such as that by parents on behalf of their children. The problems of valuing life in such contexts can be characterised in many ways. Some see it as an issue of oppressive state

${ }^{21}$ Rachael Mulheron ‘Trumping Bolam: A Critical Legal Analysis of Bolitho's "Gloss” (2010) 69 CLJ 609, especially 630-5. Thanks to Tsachi Keren-Paz for this suggestion. 
interference in private family values. Others as the state acting to protect the fundamental rights of family members against those who have the most immediate power over their lives; the same circumstances that make parents best placed to bring their children up well, also magnify the possibility that they might do them harm. Other issues relate to the unacceptability of discrimination against those living disabled lives. Which perspective is to be adopted in any particular legal system is a matter of societal choice that needs to be made through legitimate political decision-making channels. ${ }^{22}$

Each of these dimensions of the problem calls to be addressed against different criteria. The scientific foundation of the available options may be regarded as amenable to expert assessment, suggesting a degree of deference to appropriately qualified practitioners but within a framework for accountability. Appetite for risk is a personal matter on which a wide range is observed, suggesting that a margin of tolerance should be expected in the regulation of innovation. The value of life is a matter for legal regulation on behalf of society; either positively in terms of an expression of how the sacredness should be promoted, or negatively in terms of reasons that are proscribed as unacceptable (such as discriminatory quality of life assessments that relate to legally protected characteristics). ${ }^{23}$

A fundamental task of bioethics governance is to find mechanisms that can serve to respect moral pluralism, while rejecting the idea that morality does not matter (relativism) or is merely an exercise in which social power must be accepted at face value (nihilism). ${ }^{24}$ The aim of this article is to discuss the governance framework for

${ }^{22}$ See the special issue of the Journal of Medical Ethics (2018) 44(7) for examples of the range of approaches.

${ }^{23}$ Equality Act 2010, 4, covering: age; disability; gender reassignment; marriage and civil partnership; pregnancy and maternity; race; religion or belief; sex; sexual orientation.

${ }^{24}$ Jonathan Montgomery, 'Bioethics as a Governance Practice' (2016) 24(1) Health Care Analysis 3; Jonathan Montgomery, 'Modification of the human genome: Human rights challenges raised 
difficult decisions to be taken on the deployment of untested therapies in ways that account for the possibilities that optimism may lead to harm, without disrespecting the legitimacy of the motivations of the parties. The next section considers how regulation of clinical decisions to give treatments might be structured. The subsequent section examines the regulation of the giving of consent to treatments. The final section considers the Charlie Gard case in the light of this framework.

\section{Structuring clinical decisions: the appropriateness of treatment}

Health care law in England is predicated on an implicit and quasi-contractual structure under which professionals offer treatment options to patients and patients choose whether to accept them. ${ }^{25}$ The law regulates the decisions of clinicians whether to provide treatments primarily by asking whether they meet the expected professional standards, a test that is applied whether or not the patient is competent to consent. ${ }^{26}$ Clinicians are bound to sustain life where all reasonable professionals would do so, ${ }^{27}$ but are not obliged to provide treatment merely because patients (or parents) desire it, ${ }^{28}$ nor to give care that they cannot conscientiously deliver. ${ }^{29}$ Occasionally, patients are precluded by law from accepting, and professionals are prohibited from offering,

by scientific and technological developments' In $20^{\text {th }}$ Anniversary of the Oviedo Convention: relevance and challenges (2017) Proceedings, Council of Europe 60-72.

${ }^{25}$ Aintree UH NHST v James [2013] UKSC 67, but see also Sidaway Bethlem RHG [1985] 1 AC 871, 904 (Lord Templeman).

${ }^{26}$ Aintree ibid [18].

${ }^{27}$ Airedale NHST v Bland [1993] 1 FLR 1026. Failure to keep patients alive in those circumstances is likely to give rise to criminal and professional disciplinary sanctions as well as civil liability.

${ }^{28}$ Burke v GMC [2005] EWCA Civ 1003; $N$ v ACCG [2017] UKSC 22, in particular [35], [44]; NHST $v$ Y [2018] UKSC 46.

${ }^{29}$ Re J [1992] 4 All ER 614; AVS (by his litigation friend CS) v A NHS Foundation Trust [2011] EWCA Civ 7. 
treatments that they might otherwise think ethical (as in relation to abortions). ${ }^{30}$ This might be considered as a constraint on the 'licence to offer' that medical registration confers.

Given the regulation of medicines that was introduced to avoid the repetition of the Thalidomide scandal, ${ }^{31}$ it might be thought that the professional discretion is limited by laws protecting patients from untested products. In fact, in the UK, general licensing restrictions on the use of medicines are suspended where doctors choose to use them for individual patients. ${ }^{32}$ This provision permits the supply of medicines to fulfil the 'special needs' of a patient as assessed by the prescriber. There is no regulatory scrutiny as with the extended access or 'compassionate use' provisions in USA law, ${ }^{33}$ (although these themselves are under pressure from so-called 'right to try' provisions). ${ }^{34}$

The 'ethical plausibility' of right to try laws, popular with publics (but generally not with experts, and not always with industry), is based on the perception that

${ }^{30} R(A \& B) v$ Sec State for Health [2017] UKSC 41, [94] (Hale) analysing the significance of the Offences against the Person Act 1861 and the Abortion Act 1967. See also Rv BM [2018] EWCA Civ 560 on body modification. Thanks to Jean McHale for directing me to the latter case.

${ }^{31}$ Harvey Teff, 'Regulation under the Medicines Act 1968: continuing prescription for health' (1984) 47 MLR 303-23.

${ }^{32}$ Human Medicines Regulations 2012, SI 2012/1916, Regulation 167. See Medicines and Healthcare products Regulatory Agency, The supply of unlicensed medicinal products ("specials") Guidance Note 14 (MHRA 2014) and advice on 'Off-label or unlicensed use of medicines: prescribers' responsibilities' https://www.gov.uk/drug-safety-update/off-label-orunlicensed-use-of-medicines-prescribers-responsibilities (accessed 3 October 2018).

${ }^{33}$ See

https://www.fda.gov/downloads/Drugs/GuidanceComplianceRegulatoryInformation/Guidances/ UCM432717.pdf. In EU law, 'compassionate use' means something slightly different and relates to groups of patients, see Article 83 (2) of Regulation (EC) No 726/2004. Individual patient compassionate usage is regulated by national authorities, see European Medicines Agency, Questions and answers on the compassionate use of medicines in the European Union (EMA 2010) http://www.ema.europa.eu/docs/en_GB/document_library/Other/2010/01/WC500069898.pdf (accessed 27 July 2018).

${ }^{34}$ For the campaigns over the 'right to try' see http://righttotry.org/about-right-to-try/ (accessed 27 July 2018). The Federal legislation is The Right to Try Act 2017, 21 U.S.C. 360bbb-0a. 
regulation hinders innovation, and that innovation is motivated (like medical research) by the pursuit of cures. ${ }^{35}$ However, in the absence of standards, it may permit character flaws to go unrestrained. Commentators have identified a number of particularly relevant issues. Denise Myerson has argued that there is an inherent risk amongst innovators of optimism bias, which should be countered by establishing a presumption against innovation that needs to rebutted by evidence. ${ }^{36}$ Kasper Raus has raised a series of concerns. These include the risk that claims to be beneficent or respect patient autonomy may actually be exploitative of vulnerable people. He also notes the possibility that unregulated experimental use of medicines might undermine scientific method by proceeding enthusiastically, rather than systematically, and be self-serving on the part of commercial interests. ${ }^{37}$ There were hints of such problems in the Gard case. $^{38}$

In partial recognition of the problem that there might be a tension between science and the demand for unproven therapies, it has been suggested that patients are under a moral obligation to accept monitoring of effects and to agree to share information if they benefit from innovative therapies. ${ }^{39}$ The risks of over-optimism on

${ }^{35}$ Daniele Carrieri, Fedro Paeccatori, and Giovanni Boniolo, 'The ethical plausibility of the 'Right To Try' laws' (2018) 122 Critical Reviews in Oncology/Hematology 64-71.

${ }^{36}$ Denise Meyerson, 'Innovative surgery and the precautionary principle' (2013) 38 Journal of Medicine and Philosophy 605-624.

${ }^{37}$ Kasper Raus, 'An analysis of common ethical justifications for compassionate use programs for experimental drugs' (2016) 17 BMC Medical Ethics 60.

${ }^{38}$ Great Ormond Street Hospital position statement at High Court 24 July 2017, para 10, available at https://www.gosh.nhs.uk/news/latest-press-releases/gosh-position-statement-issued-highcourt-24-july-2017 (accessed 31 July 2018).

${ }^{39}$ Mary Walker, Wendy Rogers and Vikki Entwistle, 'Ethical justifications for access to unapproved medical interventions: an argument for (limited) patient obligations' (2004) 14(11) Am J Bioeth 3. 
the part of patients are partly addressed by bringing them within the evidence gathering process.

Industry has not ignored its moral responsibilities in relation to compassionate use of unproven products. In the USA, independently of the 'right to try' movement, some companies have developed their own governance procedures. Janssen has commissioned bioethicists to develop a model aimed to be 'transparent, fair, beneficent, evidence-based, and patient-focused'. ${ }^{40}$ The key issue was fairness. They put in place a standardised format for requests and provided for anonymity in consideration, in order to reduce biases. It also promoted principles of justice: including 'needing to exhaust all existing approved treatments, the scientific likelihood of an efficacious response, patient functionality...' Finally, the availability of an appeal provides assurance that the intended process has been followed. Such initiatives can be seen to use procedural tools to promote good decision-making in relation to the 'offer' of untested therapies and to avoid the risk of over-enthusiasm. ${ }^{41}$

In the UK, personal therapeutic use sits outside the regulation of research as well as the regulation of medicines. In some UK hospitals, including GOSH where Charlie Gard was being cared for, clinical ethics committees can provide support or oversight of therapeutic innovation. In others there are medicines committees, drugs and therapeutics panels, new procedures committees and other clinical governance structures. ${ }^{42}$

${ }^{40}$ Arthur Caplan et al., 'Fair, just and compassionate: A pilot for making allocation decisions for patients requesting experimental drugs outside of clinical trials' (2018) Journal of Medical Ethics online publication 7 July 2018, http://dx.doi.org/10.1136/medethics-2016-103917.

${ }^{41}$ Denise Meyerson, 'Medical Negligence Determinations, the 'Right to Try,' and Expanded Access to Innovative Treatments' (2017) 14(3) Bioethical Inquiry 385-400.

${ }^{42}$ See Simms v Simms \& An NHST [2002] EWHC 2734 (Fam), [68]-[70], [74] and for an example of less formal procedure, see Stephen Wigmore, Special Inquiry into Regenerative Medicine Research at UCL (2017) 19, available at https://www.ucl.ac.uk/news/newsarticles/0917/Special_Inquiry Final Report 605109702 7 .pdf (accessed 9 November 2018). 
However, such committees have no recognised legal status, and there are no common standards. ${ }^{43}$ In Simms, it was noted that (despite this being undesirable) clinical ethics committees 'must exercise their own discretion' and might decide not to support treatment that a court had considered both to be lawful and also in the best interests of the patient. ${ }^{44}$ This demonstrates a distinction between the lawfulness of offering a treatment from the decision actually to administer it. The latter decision can be a matter for the individual clinician or health provider. The former is about compliance with a more objective standard.

In relation to more established treatments, professional discretion in relation to offering treatments is usually guided, although rarely limited, by clinical guidelines. In relation to treatment of children, the Royal College of Paediatric and Child Health gives guidance on how to approach decisions. ${ }^{45}$ It was applied by the President of the Family Division in Re Jake (a child) (withholding of medical treatment) as the main mechanism for assessing whether the care proposed was in the child's best interests. ${ }^{46}$ It was adopted as part of the framework governing court decisions by Hayden $\mathrm{J}$ in the Alfie Evans case, ${ }^{47}$ and relied upon by both the judge and experts in assessing options in the Isaac Haastrup case. ${ }^{48}$ None of these decisions involved innovative treatments, but they were cases in which the health professionals did not believe that it was appropriate to

${ }^{43}$ For information, see the UK Clinical Ethics Network website, http://www.ukcen.net/main.

${ }^{44}$ Simms (n 42) [70]. Only if the treatment would have been given by all reasonable practitioners would treatment be mandatory, see fn 27 . It does not become mandatory as a result of the best interest decision but at the stage of assessing lawfulness.

${ }^{45}$ Vic Larcher and others 'Making Decisions to limit treatment in life-limiting and life-threatening conditions in children: a framework for practice' Arch Dis Child 2015;100(Suppl 2):s1-s26. doi:10.1136/archdischild-2014-306666. This was a development from earlier guidance.

${ }^{46}$ [2015] EWHC 2442 (Fam).

${ }^{47}$ Alder Hey Children's NHSFT v Evans [2018] EWHC 308, [46].

${ }^{48}$ King's College NHSFT v Haastrup [2018] EWHC 127 (Fam), [30], [43], [74]. 
offer treatments that the parents wanted, and in which the courts confirmed that the professional view was appropriate and should prevail.

Although not directly concerned with innovative therapies, these guidelines provide an important context to the Charlie Gard case for two reasons. First, in providing a point of reference for the third type of issue that was identified in the introduction - the valuing of life and its 'quality' in the light of available options - on behalf of society, through professional consideration, under the oversight of the judiciary. Second, in establishing the importance of collective professional deliberation. In the leading informed consent case, Montgomery $v$ Lanarkshire $H B$, the UK Supreme Court drew a distinction between issues of 'divergent attitudes amongst doctors' and those aspects of practice 'determined by medical learning or experience' ${ }^{49}$ Matters in the latter category were legitimately governed by professional standards via the Bolam test ${ }^{50}$ but those in the former were thought to be driven by the personal, rather than professional, judgment of clinicians. In relation to disclosure requirements, this led to a patient-centred test of what risks are material; privileging patient assessments of how risks are to be valued over professional ones. ${ }^{51}$

In Montgomery itself the Supreme Court judged that the doctor was driven by a personal moral preference for vaginal delivery rather than assessment of risk. ${ }^{52}$ Although this view is difficult to reconcile with the assessment of the judge who heard the evidence in the case,${ }^{53}$ it indicates a concern to protect patients from non-evidence-

${ }^{49}$ [2015] UKSC 11 [84].

${ }^{50}$ Bolam v Friern HMC [1957] 2 All ER 118.

${ }^{51}$ Montgomery (n 49) [87].

${ }^{52}$ Ibid [114] (Lady Hale).

${ }^{53}$ Jonathan Montgomery \& Elsa Montgomery, 'Montgomery on informed consent: An inexpert decision?' (2016) 42(2) Journal of Medical Ethics, 89-94. 
based decisions masquerading as technical expertise. It is not yet clear whether the view in Montgomery that it was for the court to control the test to be applied in cases where there were concerns that personal values would dominate rather than collegiate ones extends beyond the context of information disclosure. ${ }^{54}$ However, the Supreme Court's analysis of the conscientious objection provisions in the Abortion Act 1967 suggests a narrow interpretation of such statutory rights, which protect personal rather than professional values, and a focus on good organizational practice to accommodate staff concerns of conscience. ${ }^{55}$

There is limited judicial authority on whether health professionals can offer experimental therapies without being vulnerable to a malpractice suit. ${ }^{56}$ The fullest discussion of the issues has come in the Simms case, concerning a novel treatment for nvCJD for two young patients. Elizabeth Butler-Sloss P summarized the law:

In a situation where there is no application to the court, and the patient does not have capacity to make a decision about medical or surgical treatment, the doctor has, in my judgment, two duties. First, he must act at all times in accordance with a responsible and competent body of relevant professional opinion.... There is a second duty... he must act in the best interests of a mentally incapacitated patient. ${ }^{57}$

In the first stage, therefore, the doctor must determine 'whether the treatment does come within the 'Bolam test' ${ }^{58}$ In relation to the second stage, Butler-Sloss

${ }^{54}$ For discussion of this issue, see Jonathan Montgomery, 'Patient No Longer? What's next in Health Care Law' (2017) 70 Current Legal Problems 73-109.

${ }^{55}$ Jonathan Montgomery, 'Conscientious Objection: personal and professional ethics in the public square' (2015) 23(2) Med Law Review 200, discussing Greater Glasgow HB v Doogan [2014] UKSC 68.

${ }^{56}$ Sara Fovargue, Xenotransplation and Risk (Cambridge 2012) 70-79.

${ }^{57}$ Simms (n 42) [42].

${ }^{58}$ Ibid [46]. 
suggested that the best interests duty on doctors was identical to that of parents and the courts, ${ }^{59}$ suggesting an alignment of legal expectations. For adults, the law has been codified since the decision in Simms. It would be governed by the Mental Capacity Act 2005, and would turn on whether the doctor 'reasonably believes... that it will be in [the patient's] best interest' to give the care in question, ${ }^{60}$ having considered the issues and undertaken the consultations prescribed in section 4 of that Act. The basic framework that Butler-Sloss proposed, therefore, remains intact. Indeed, the Mental Capacity Act specifically provides that it does not affect liability in civil actions for negligence. ${ }^{61}$ The protections that it provides are limited to those that would be granted by a consent if the person had capacity to give one and had in fact consented. ${ }^{62}$ The first stage of the Butler-Sloss framework remains governed by the Bolam test, although that test continues to be the subject of scrutiny. ${ }^{63}$

Turning to the circumstances of the case, she noted that some benefit could not be ruled out, and in such circumstances

Where there is no alternative treatment available and the disease is progressive and fatal, it.. [is] reasonable to consider experimental treatment with unknown benefits and risks, but without significant risks of increased suffering to the patient. A patient who is not able to consent to pioneering

${ }^{59}$ Butler-Sloss P incorporated Lord Goff's explanation that the law required doctors to make choices about care 'in exactly the same way as would the court or reasonable parents in relation to a child' from Re F (Mental Patient: Sterilisation) [1990] 2 AC 1, 77, cited in Simms (n42) [44].

${ }^{60} \mathrm{~S} 5(1)$ (b). NB in $U C L H v K G$ [2018] EWCOP 29, [32]-[33] Cohen J expresses the view that Bolam is not relevant to the MCA decision and that the decision in Simms was 'an additional level of test' that was not 'helpful'. For reasons set out in the text, my view is different. According to a twitter exchange between the author and Victoria Butler-Cole on 7 November, there was only five minutes discussion of this point in court.

${ }^{61} \mathrm{~S} 5(3)$.

${ }^{62} \mathrm{~S} 5(2)$.

${ }^{63}$ See Mulheron (n 21) and Montgomery (n 54). 
treatment ought not to be deprived of the chance in circumstances where he would have been likely to consent if he had been competent' ${ }^{64}$

This assesses clinical decisions on whether it is appropriate to offer treatment (a judgment that is required of clinicians irrespective of the capacity of the patient) by reference to a peer review standard. English courts have long recognised that this does not require the 'stagnation' of practice. ${ }^{65}$ It has also been recognised that a small group of specialist innovators could constitute a responsible body of opinion. ${ }^{66}$ In the light of these principles, assertions by politicians that this area of law provides a barrier to innovation seem misguided, ${ }^{67}$ but the need to establish that an innovator can gain the support of peers for their approach remains a crucial protection against over-optimism. This does not require that a second opinion is sought prior to an innovative treatment, but it does suggest that some form of second opinion process might be prudent. In relation to incapacitated patients, it has been held that a supportive second opinion can preclude the need for court referral in cases where the appropriateness of treatment is unclear to the clinicians concerned, even when such referral would generally be expected, as it establishes that the clinician is acting properly. ${ }^{68}$

More broadly, however, there has been a tendency to seek to control the medicalization of decisions at the margins of established practice by requiring court review in cases, at least in circumstances where patient autonomy cannot provide a counter-balance to medical enthusiasm. This was mandated initially in relation to non-

${ }^{64}$ Simms (n 42) [57]-[58].

${ }^{65}$ Sidaway (n 25) (Lord Diplock).

${ }^{66}$ De Freitas v O'Brien [1995] EWCA 28; [1995] 25 BMLR 51, [59].

${ }^{67}$ Jose Miola, 'Bye Bye Bolitho? The Curious Case of the Medical Innovation Bill' (2015) 15 Medical Law International 124-154.

${ }^{68} \operatorname{Re} G F$ [1992] 1 FLR 293. 
therapeutic sterilizations of adults who lacked capacity, ${ }^{69}$ and subsequently for patients in persistent vegetative states ${ }^{70}$ when the courts asserted that such cases should be brought to court for review. Judges have mooted that non-regenerative organ donation might also need to come to court, ${ }^{71}$ and there are mixed dicta in relation to abortions. ${ }^{72}$ At common law, court referral was a matter of good practice rather than a precondition of legality. ${ }^{73}$ That expectation was codified in Practice Direction 9E, Applications Relating to Serious Medical Treatment, issued to supplement the Court of Protection Rules $2007 .^{74}$ This included in the categories of 'serious medical treatment' for which a court application is expected 'experimental or innovative treatment' and those 'involving an ethical dilemma in an untested area' (6(d) and (e)). Thus, under the law in place until December 2017, if Charlie Gard had been an incapacitated adult, the governance framework would have required referral of the option of nucleoside treatment to court. Practice Direction 9E was withdrawn in that month, and it is unclear whether it will be replaced. ${ }^{75}$ The Supreme Court has ruled that court review is not always required where families and health professionals agree that clinically assisted nutrition and hydration should not be provided to permanently incapacitated patients. ${ }^{76}$

${ }^{69} \operatorname{Re} F(\mathrm{n} 59)$.

${ }^{70}$ Bland (n 27).

${ }^{71} \operatorname{Re} F$ [1989] 2 FLR 376; Re $Y$ [1996] 2 FLR 787.

${ }^{72}$ Re F ibid; Re $S G$ [1991] 2 FLR 329.

${ }^{73}$ Burke (n 28) [67]-[80].

${ }^{74}$ Available at https://www.judiciary.gov.uk/wp-content/uploads/2015/06/copd-pd-9e-seriousmedical-treatment.pdf (last accessed 3 October 2018).

${ }^{75}$ Alex Ruck Keane 'New PDs now published (and one that hasn't been)' https://courtofprotectionhandbook.com/2017/11/06/new-pds-now-published-and-one-that-hasntbeen/ (last accessed 3 October 2018). See also NHST v Y (n28), [51]-[52] and the MCA Code of Practice paras 6.18-9 and 8.23 which have not been updated and still envisage court referral for 'untested and innovative treatments'.

${ }^{76}$ NHST $v Y$ (n 28). For interim guidance for clinicians from the GMC, Royal College of Physicians and the BMA, see https://www.gmc-uk.org/-/media/ethical-guidance/related-pdf- 
However, the case did not concern unproven treatments. In $U C L H v K G$, the Court of Protection approved the first ever treatment of an incapacitated patient suffering from prion disease with a humanised monoclonal antibody known as PRN100. It was suggested that it was premature to interpret the Supreme Court decision as meaning that there would be no need to refer such cases in the future if 'the patient and his/her family are in agreement. ${ }^{77}$

Court referral is a mechanism for ensuring that health professionals account to a third party for their decisions to offer potentially controversial practices to patients. It was envisaged that as a body of case law built up, 'experience and practice' would crystallize so that there would not need to be an application in every case. ${ }^{78}$ This position now seems to have been reached in relation to the withdrawal of clinically assisted nutrition and hydration where family and clinicians (supported by an external specialist opinion) are in agreement. ${ }^{79}$ This approach revolves on uncertainty. Court referral is appropriate while better understanding is being developed and should be mandatory while the situation remains unclear. ${ }^{80}$

In relation to the court oversight of sterilization questions, Lord Brandon offered an alternative rationale, by reference to characteristics of the specific situation. Situations calling for referral include: (a) the possible deprivation of a fundamental human right; (b) where significant moral and emotional issues arise; (c) in order to

items/end-of-life-care/making-decisions-to-withdraw-canh-from-patients-in-pvs-and-mcs.pdf (last accessed 3 October 2018).

${ }^{77}$ (n 60) [29]-[30]. The patient, although lacking capacity was capable of expressing his views, hence the reference to his agreement.

${ }^{78}$ Bland (n 27) at 805, 815-6, 859, 873--4.

${ }^{79}$ NHST v Y (n 28), Re M (Withdrawal of treatment: Need for Proceedings) [2017] EWCOP 19.

${ }^{80}$ Mr Justice Baker, 'A matter of life and death' (2017) 43 Journal of Medical Ethics 427-34. 
reduce the risk of error; and (d) to ensure the exclusion of improper considerations. ${ }^{81}$

These seem relevant to cases where treatments of uncertain efficacy and side effects are considered, especially those in which the treating clinicians may have a vested interest (whether financial or reputational). Judicial oversight serves in such cases to control the risks of medical hubris. It would seem wise for this aspect of Practice Direction 9E to be restored.

\section{Structuring decisions: the parental power to consent}

The previous section examined the regulation of clinical decisions to offer treatment, including the need for court referral. We now turn to questions of the patients' rights to consent. First, there may be some circumstances in which consent to innovation could be deemed ineffective by the law. This was examined as a serious question in relation to the legality of consents to organ donation in the early days of transplantation. ${ }^{82}$ It is now generally agreed that a competent adult patient's consent to 'proper medical treatment' will be valid, ${ }^{83}$ as the fact that the medical treatment is 'proper' provides an exception to the normal rule that consent to physical harm is not effective to absolve the assailant of liability. ${ }^{84}$ If Charlie Gard had been a competent adult, then providing that it was proper to offer the nucleoside treatment (see the previous section), it would seem also that a valid consent could have been given. However, it does not necessarily follow

${ }^{81} \operatorname{Re} F$ (n 59) 56.

${ }^{82}$ Gerald Dworkin, 'The Law Relating to Organ Transplantation in England' (1970) 33 Modern Law Review 353, 355-64.

${ }^{83}$ Margaret Brazier and Sara Fovargue, 'Transforming Wrong into Right: What Is "Proper Medical Treatment"?' in Sara Fovargue and Alexandra Mullock (eds) The Legitimacy of Medical Treatment: What Role for the Medical Exception? (Routledge 2015) 12-31; Penney Lewis 'The Medical Exception' (2012) 65 Current Legal Problems 355-76.

${ }^{84}$ Attorney General's Reference (No 6 of 1980) [1981] QB 715. Possibly subject to its vitiation by misrepresentation if the offer to treat had been legally improper $R v$ Tabaussum [2000] Lloyds Medical Reports 404. 
that the parental power to give a proxy consent extends to the same degree as personal decisions.

The law regulating the decisions of adult patients turns on their competence, and prevents further questions being asked about the wisdom of decisions. Competent adults are entitled to have their decisions respected even if they are irrational or no reasons are given. ${ }^{85}$ Capacity law provides decision-making structures in relation to adults who lack capacity to make their own choices that are aimed to ensure that their own conceptions of their interest are reflected as closely as possible,${ }^{86}$ an intention not perfectly realised in practice. ${ }^{87}$ In relation to minors, the Children Act 1989 provides for protective court oversight in cases of dispute to ensure that adult interests do not compromise those of children (see further below), but the law also regulates the possibility that parents may not have their children's best interests at heart by limiting the validity of their consents. This puts some parental choices beyond their legal powers.

The courts have concluded that there are some categories of medical treatment where parental consent is invalid. They have expressly determined this in relation to non-therapeutic sterilization. ${ }^{88}$ They have suggested that non-regenerative organ donation might also be included, ${ }^{89}$ although this is not a uniform view. ${ }^{90}$ There are also some decisions that can only be taken where all those with parental responsibility agree, making unilateral parental consents invalid. These include male circumcision, at least

${ }^{85}$ Sidaway (n 25).

${ }^{86}$ Mental Capacity Act 2005, s 4(6).

${ }^{87}$ Select Committee on the Mental Capacity Act, Mental Capacity Act 2005: post-legislative scrutiny (2014) HL Paper 139.

${ }^{88} \operatorname{Re} B$ [1987] 2 All ER 206, 214 (Templeman).

${ }^{89}$ See Re F (n 59) 413 (Butler-Sloss LJ).

${ }^{90} \operatorname{Re} W[1992] 4$ All ER 627, 635 (Donaldson MR). 
where there is a known dispute between the parents, ${ }^{91}$ and immunization. ${ }^{92}$ There has been only limited judicial application of these principles to medical innovations. In the Jaymee Bowen case, concerning whether an 'experimental therapy' should have been funded it seemed to be assumed that it would have been lawful to administer it, and it went ahead privately on the basis of parental consent without any court oversight. ${ }^{93}$ However, the case paid little attention to the nature of the therapy (rather than prospects of success) and the health authority was unable to adduce evidence to support its claim that it was merely experimental. There is no direct authority to show that parents have the power to consent to experimental treatment, but it is widely believed that this is permissible provided that the child is not harmed in the process. ${ }^{94}$

This does not conclude the issue of parental consent, however, as it is also necessary to consider the exercise of the power to authorise treatment in specific cases. In Simms, Butler-Sloss P considered this was a matter of the best interests test. Having established that the treatment in that case could properly be given within the Bolam test, she went on to examine whether it was in fact in the interests of the young people to go ahead with it. Thus, a treatment might be legally available, but not appropriate in the circumstances. As the patients' proxy, she was satisfied that it was 'a reasonable risk to

${ }^{91}$ Re J (specific issue orders: Muslim upbringing and circumcision) [1999] 2 FLR 678; affd [2000] 1 FLR 571, CA.

${ }^{92} \operatorname{Re} C$ (welfare of child: immunisation) [2003] EWCA Civ 1148.

${ }^{93} R v$ Cambridge DHA, exp B [1995] 2 All ER 129.

${ }^{94}$ For discussion of the controversy, see Gerald Dworkin, 'Legality of consent to non-therapeutic medical research on infants and young children' (1978) 51 Archives of Diseases in Childhood 443-446 and Jonathan Montgomery, 'Informed Consent and Clinical Research with Children' in Len Doyal \& Jeffrey Tobias (eds) Informed Consent in medical research (BMJ Books 2001) 173-79. 
take on their behalf. ${ }^{95}$ As seen above, she regarded the role of the judge here as the same as parents exercising their power to consent.

The Gillick case made it clear that parental rights are held in order to pursue the interests of their children, not as some independent and unaccountable power of parental privacy. ${ }^{96}$ It follows that the law is concerned to ensure that the motivation for parental decisions is child-centred. In cases where it is thought that strong religious, ${ }^{97}$ or ideological, ${ }^{98}$ positions make it impossible for parents to consider options objectively, then the application of the best interest test serves to override their views as misdirected. It will be rare that this invalidates a decision, but it may well make it appropriate for clinicians to refer a matter to court. Discussing the merits of a liver transplant that was opposed by parents, Waite LJ distinguished between dogmatic opposition "patently irreconcilable' with the child welfare and cases 'where there is genuine scope for a difference of view between parent and judge, 99

It is also possible to envisage that a decision based upon a mistake, such as the belief that HIV was not the cause of AIDS, ${ }^{100}$ might be considered ineffective. It might also be that parents fail to pass the test for legal capacity in relation to an exercise of the power to consent if they lack understanding of the issues, or do not accept the nature of the circumstances that present themselves for decision. These are all issues raised by the

${ }^{95}$ Simms (n 42) [62].

${ }^{96}$ Gillick $v$ W Norfolk [1985] 3 All ER 402, see especially the discussion in R (Axon) $v$ Sec State for Health [2006] EWHC 37 (Admin).

${ }^{97} \operatorname{Re} C$ (SMA-1) [1998] 1 FLR 384.

${ }^{98} \operatorname{Re} C$ (A child) (HIV test) [1999] 3 FCR 289.

${ }^{99} \operatorname{Re} T$ [1997] 2 FCR 363, 374-5.

${ }^{100} \operatorname{Re} C(\mathrm{n} 98)$. 
facts of Gard. Parents are entitled to due process when their views may be overridden, but not necessarily for their opinions to prevail. ${ }^{101}$

\section{Reflections on the Gard case}

It is now time to consider what can be gleaned from the court proceedings about the circumstances of the Gard case and how the principles that have been discussed might be applied. The purpose in this section is to show how the metaphor of tragedy illuminates the issues that the litigation uncovered. First, focusing on the legality of the offer of treatment, we can see how the Gard case exposes the way in which optimism becomes medical hubris when unchallenged by regulatory processes. Second, I consider regulatory options in relation to concerns over the rationality of parental decision making.

\subsection{Medical hubris}

It is unclear whether the treatment proposal from Dr Hirano (described as Dr I in the extracts below) would have fallen within the scope of responsible professional practice, as measured against the Bolam test so as to avoid liability in negligence. First, the existence of colleagues who in fact backed it was unclear. In court, it was stated that 'Save for Dr I... the body of experienced medical opinion available to the judge... was unanimous to the effect that the prospect of nucleoside treatment having any benefit was effectively zero and would be futile.' ${ }^{102}$ This included the independent expert instructed by the family. There were signatories to letters from across the world, but none of the doctors who had any direct knowledge of the case supported the treatment other than Dr

${ }^{101}$ Glass v UK [2004] 1 FLR 1019; NHST v AB [2016] EWCA Civ 899 [32].

${ }^{102}$ Gard CA (n 7) [15]. NB this futility was independent of any disagreement about the quality of life that might be secured, it related only to securing improvement in brain function. 
Hirano. Unlike Dr Hirano and the doctors from the UK, their views were untested in any proceedings. Yet they gave hope to the parents and fueled media speculation despite lacking any basis on which to give an expert assessment.

As the case turned on a judicial assessment of where Charlie's best interests lay, the malpractice test was not directly considered and Dr Hirano was not required to defend his judgment to avoid liability. However, the judicial scrutiny of his reasoning drew attention to weakness of its rationale which lacked 'scientific evidence'. 103 It is possible that a court would have considered that the proposal was so unable to withstand logical analysis as to justify a court holding the medical practice to be negligent under the decision in Bolitho even if there had been expert support. ${ }^{104}$ In the absence of both such informed support and a logical basis for the hope Dr Hirano was offering, then it seems arguable that he would have breached the standard of care required of him by the law had he gone ahead with the treatment.

There is sufficient concern here about the scientific justification for the proposed innovation to make court oversight attractive. However, there is more to the regulatory concern about excessive medical optimism than the science. The law also needs to be satisfied that Dr Hirano could have offered this treatment in good faith. It is significant that he continued to propose the treatment even in the face of overwhelming clinical opposition to his views. At the trial on 11 April 2017 Dr I 'accepted that his opinion was based purely on theory, with no clinical evidence to support it. ${ }^{105}$ Yet, he wrote to the parents on 22 May 2017 expecting 'the therapy will be beneficial' and that

${ }^{103}$ Gard (n 5) [106], noted at Gard CA (n7) [25].

${ }^{104}$ Bolitho v City \& Hackney HA [1997] 4 All ER 771 (HL).

${ }^{105}$ Gard CA (n 7) [24]. 
'...Ideally, the treatment will ameliorate the seizures and allow more normal brain functions.' ${ }^{106}$

That expectation of benefit is in direct conflict with his evidence to the court, in which he stated that the treatment was 'unlikely to work' and that

the chances of meaningful recovery would be small, which he agreed, could not be distinguished from vanishingly small... there was only a small chance of meaningful brain function.... He conceded that to a large extent, if not altogether, the damage was irreversible. ${ }^{107}$

There is no evidence that Dr Hirano, who had not examined Charlie at that stage, took any notice of the fact that there was 'a consensus amongst all of the consultants and doctors who have examined Charlie that nucleoside treatment is futile' ${ }^{108}$ Indeed, according to Katie Gollop QC, he stated in evidence to the Court on 13 July that

not only had he not visited the hospital to examine Charlie but in addition, he had not read Charlie's contemporaneous medical records or viewed Charlie's brain imaging or read all of the second opinions... or even read the Judge's decision made on 11 April. ${ }^{109}$

These matters give rise to considerable concern that medical hubris may have overtaken expert clinical judgment. There was no clear evidence that Dr Hirano had contemplated the possibility that he might be mistaken or considered the views of others. It was also suggested that he retained a financial interest in some of the products

${ }^{106}$ Ibid [27].

${ }^{107} \operatorname{Gard}(\mathrm{n} 5)$ [105].

${ }^{108}$ Ibid [126].

${ }^{109}$ Katie Gollop QC, 'Great Ormond Street position statement at the High Court, 24 July 2017', para 10, https://www.gosh.nhs.uk/news/latest-press-releases/gosh-position-statement-issuedhigh-court-24-july-2017 (last accessed 4 June 2018). 
that he proposed prescribing, ${ }^{110}$ giving rise to concerns of potential conflict of interests that suggest regulation is appropriate in order to constrain his enthusiasm before it led to tragic consequences.

In Sidaway, Lord Templeman noted that the court would be slow to conclude that a doctor had breached their duty to the patient where he or she 'conscientiously endeavours to explain the argument for and against... and the possibilities of benefiting

and the dangers.' ${ }^{111}$ However, Dr Hirano's dealings do not look very conscientious. He offered confident opinions on limited evidence and long before he had made any clinical observations. The apparent lack of interest from Dr Hirano in collaborative exploration of the science, or of the clinical circumstances in which Charlie found himself, contrast with the actions of GOSH. That hospital sought additional opinions and opened up its decision-making to court scrutiny, including bringing back to court a claim that there was new evidence that they believed mistaken but recognising the importance of an independent assessment. ${ }^{112}$ While Dr Hirano pursued his personal assessment despite the evidence, GOSH acknowledged the authority of others. Only the court's oversight exposed the weakness of the basis of his proposal of treatment.

\subsection{Parental decision-making}

The law relating to the validity of specific parental decisions is also unexplored in the Gard judgments. This is because the cases were brought to court to resolve the substantive 'best interest' questions rather than as a question of the legal scope of

\footnotetext{
${ }^{110}$ See $\mathrm{n} 38$.

111 Sidaway (n 25) 903.

${ }^{112}$ See Gard II (n 5).
} 
parental rights. However, the general framework of consent law would suggest that it is necessary to consider three categories of questions.

First, competence to decide. Parents may lack the competence to exercise parental rights; perhaps due to lack of capacity to understand or a failure to appreciate the circumstances about which they must choose. In such cases the Children Act allows for court oversight, but the test for the judge is not the validity of consent but the course of action which would be in the child's best interests.

Second, interpreting the scope of the decisions that have been taken by parents, to ensure that they apply to circumstances that are actually being faced. Thus, a decision to refuse a blood transfusion that was interpreted by the court to apply to non-lifethreatening circumstances was held to be irrelevant to decisions where life or death was at stake. The same case also raised a subsidiary question about the scope of decisions based on misinformation, holding that the decision bound in the circumstances that the patient believed to be present but not in the different ones that in fact presented themselves. ${ }^{113}$

Third, the degree to which the law is concerned with the quality of reasoning. In adults, disordered reasoning may be a trigger for assessing capacity, and it is recognised that sometimes fear or pressure may 'paralyse the will' temporarily destroying capacity. ${ }^{114}$ This concerns the decision-making process, but leaves (at least in principle) the substance of the decision beyond the scope of the judges.

The Gard case can be considered in the light of these issues. There seems little doubt that the parents had the capacity to understand the issues. They spoke about them articulately in various media and before the courts. However, there is scope for debate

\footnotetext{
${ }^{113} \operatorname{Re} T$ [1992] 4 All ER 649, 663 (Donaldson MR). See also Re MB [1997] 2 FLR 649.

${ }^{114} \operatorname{Re} M B$ ibid.
} 
about both the scope of the decisions that they made and also the coherence of the reasons that they gave for them. There was a conflict with the judge about the consistency of their assessment of Charlie's quality of life. The court reported them as having agreed that Charlie's quality of life in April 2018 was not worth preserving. ${ }^{115}$ However, when the Court of Appeal suggested that this meant that the scientific finding that there was no prospect of improvement implied that it followed that it was time to permit Charlie to die, then they denied that they had in fact held that view. ${ }^{116}$ Inconsistency is not necessarily evidence of incapacity, but it raises a cause for concern that should properly trigger scrutiny. Further reason to worry that the parents might not have addressed the severity of the position came when the mother was reported in July 2017 to have said that there was 'potential for him to be a completely normal boy', ${ }^{117}$ a view that was incompatible with even the most optimistic of Dr Hirano's statements.

While these positions are a wholly understandable human response to the tragic circumstances, they might also be evidence that the parents' love had blinded them to the decision that they needed to take. The belief that Charlie could become a normal boy might have obscured the cruel reality that the best that was being offered to them was a tiny improvement and a marginally increased length of life. The refusal to acknowledge their previous assessment of the poor quality of life might indicate that they were in a form of denial of the circumstances. Possibly their decision on what was best for Charlie was addressed to a different situation and they were not really offering a view on the issue before the judge.

${ }^{115}$ Gard CA (n 7) [18]; Gard (n 5) [61].

${ }^{116}$ http://www.bbc.co.uk/news/uk-england-london-40593286 (last accessed 4 June 2018).

${ }^{117}$ https://www.mirror.co.uk/tv/tv-news/charlie-gards-mum-connie-reveals-10752328 (last accessed 4 June 2018). 
These are all reasons to provide for a referral to court as an independent tribunal in which the reasoning can be explored. That enables the components of decisions to be disentangled; with those aspects that are dependent on science and medical diagnosis being distilled out and tested against scientific standards, questions of value being placed within the proper legal framework of (under the current law) best interests rather than sanctity of life, and the matter of whether risks are worth taking aired before an independent adjudicator.

\section{Conclusion}

Whether the legal test governing disputes between clinicians and parents in relation to clinical care is best interests (as is the current law) or an alternative, the problems addressed in this piece would remain. Strong minded parties will always seek to interpret the evidence in the ways that meet the requirements of the legal tests. They will do so for the best of reasons. We should encourage in health professionals the desire to help and to overcome barriers to medical progress. We should champion the love of parents for their children and the natural instincts to protect them. However, we should also guard against the risk that these desires push people beyond rational consideration of what is at stake. It was the tragedy of Charlie Gard that it took a long and bitter fight, in the courts and through the global media, before his interests became the sole determining factor, as everyone intended that they should have been from the start.

The regulatory task is to enable that catharsis (the purification of emotions so as enable them to perform their proper role) to be achieved with less destruction. This requires clinical optimism to be tempered by ensuring the reasoning on which it is based is recognised as responsible by appropriate peers, and that a safety valve is available for independent review in contested cases. This needs not necessarily be a court, but the 
value that we place on parental responsibilities suggests that it should be a court in cases like Charlie's. ${ }^{118}$ Where clinicians or parents think that the interests of the child have been obscured, then court referral can bring these interests back to centre stage and reduce the risks of a hard case becoming a tragedy.

${ }^{118}$ Glass v UK (n 100). 